\title{
Parasitological Profile of Raw Wastewater and the Efficacy of Biosand Filter in Reduction of Parasite Ova and Cysts
}

\section{*11OKOJOKWU, OJ; INABO; HI; YAKUBU, SE}

\author{
Department of Microbiology, Faculty of Science, Ahmadu Bello University, Zaria, Nigeria
}

\begin{abstract}
KEYWORDS: Wastewater; Influent; Effluent; Ova; Cysts; Oocysts; Parasitological profile
\end{abstract}
\begin{abstract}
The disposal of wastewater in water bodies has a negative impact in the environment and the health of people who use such water bodies for either irrigation or drinking purposes. In this study, we evaluated the parasitological profile of wastewater from the Ahmadu Bello University Teaching Hospital sewage treatment plant, Zaria, Nigeria using the magnesium sulphate floatation method. The parasite removal efficiency of biosand filter was also tested in comparison with the sewage treatment plant. A total of $960 \mathrm{~L}$ of wastewater was examined and a significant level of parasite eggs, cysts and oocysts were detected. In all, 1,648 parasites eggs, cysts and oocysts per litre were counted. Ova of Ascaris spp showed the highest count/litre of 307 (18.63\%) followed by ova of Taenia spp ( $\mathrm{n}=287 ; 17.42 \%)$. The least count per litre was exhibited by cysts of Giardia $\operatorname{spp}(\mathrm{n}=58 ; 3.52 \%)$. The analysis revealed that $52.61 \%$ of the parasite eggs, cysts and oocysts was removed by the sewage treatment plant while egg removal efficiency of the biosand filter was $97.45 \%$. Further comparison of mean parasite eggs/litre in the effluents of biosand filter and the sewage treatment plant using Wilcoxon's Signed Ranks Test indicated a significant difference $(p<0.05)$ with biosand filter having lower counts per litre. The results obtained therefore demonstrate that the raw wastewater was laden with parasite eggs, cysts and oocysts and hence pose public health threat to the users of the effluent downstream. The biosand filter was more efficient than the sewage treatment plant; its effluent contains insufficient level of the ova, cysts and oocysts of parasites well below the less than one $(<1)$ helminth ova/protozoa cysts as recommended by WHO. $\odot$ JASEM
\end{abstract}

http://dx.doi.org/10.4314/jasem.v18i1.1

The practice of discharging wastewater into water bodies causes considerable damage to the ecosystem, waterfront inhabitants, swimmers, and fishermen (Hamdani and Assobhei, 2001; Paraskevas et al., 2002). Depending on its origin, wastewater can transport many pathogens depending upon the incidence of disease in the indigenous human and animal population that discharge to the sewer (Leclerc et al., 2002). Therefore, hospital wastewater is heavily laden with pathogens and toxic chemicals and hence requires adequate treatment to remove or appreciably reduce the available pathogens to a level that agrees with permissive ranges stipulated by regulatory authorities. The problem of contamination caused by the discharge of wastewater into water bodies is directly evident in intoxications, skin problems and intestinal parasitiasis (Rodriguez et al., 2004; Srikanth and Naik, 2004). This problem is compounded when these discharges are deposited in the vicinity of low-income neighbourhoods where basic hygiene practices are totally absent (Nyarango et al., 2008).
Globally, millions of people suffer from parasitic infections such as Ascariasis (1.2 billion), Trichuriasis (795 million), hookworm infections (740 million) (de Silva et al., 2003), Amoebic dysentery (50 million) (Samuel et al., 2001) and Giardiasis (2.8 million) (Ali and Hill, 2003). In humans, these parasites are significantly associated with diarrhoea (Utzinger et al., 1999). Faecal oral route is important in the transmission of parasitic infections to humans via poor personal hygiene (Okyay et al., 2004), environmental conditions like contamination of soil and water sources with human faeces (Muttalib et $a l ., 1983$ ) and poor wastewater disposal such as use of night soil for fertiliser (Mustafa et al., 2001).

This study was designed to examine the parasitological profile of the raw wastewater and effluent of the sewage treatment plant in comparison with biosand filter effluent.

\section{MATERIALS AND METHODS}

Sample collection: Samples of wastewater were collected from upstream (raw wastewater of influent) and downstream (effluent) of the Ahmadu Bello 
University Teaching Hospital sewage treatment plant, Zaria, Nigeria. A total of $960 \mathrm{~L}$ of wastewater was collected and analysed. Each sample was in volume of $20 \mathrm{~L}$. Out of the $960 \mathrm{~L}$ collected, $320 \mathrm{~L}$ was filtered through the biosand filter; the filter effluent (filtrate) was collected and analysed. Another 320 litres of raw wastewater was analysed for parasite ova, cysts and oocysts without filtering it through the biosand filter. The third phase of sample collection involved the collection of $320 \mathrm{~L}$ of effluent from the sewage treatment plant.

The method of concentration which seems the most successful in the parasitological analysis of the samples was selected based on previous studies. The method of USEPA (2005) as modified by Lim et al. (2007) was adopted with slight modification.

Sample processing: Forty litres (40 L) of raw wastewater was collected in two portions of $20 \mathrm{~L}$ volume while 20 of effluent of the effluent (treated wastewater) was collected in another container. Each 20 litre sample was concentrated by repeated centrifugation at $1500 \times \mathrm{g}$ for 15 minutes in $250 \mathrm{ml}$ conical bottomed centrifuge tubes and the supernatant was carefully discarded. The deposit (pellet) was slowly under-layered with $10 \mathrm{ml}$ of magnesium sulphate floatation solution of specific gravity 1.3 and further centrifuged at $1000 \times \mathrm{g}$ for 5 minutes. The magnesium sulphate floatation solution was filled to the brim and a cover slip was superimposed and allowed to stand for $15-20$ minutes. The cover slip was lifted and examined under a light microscope (Olympus Microscope XSZ - 107BN No. 001677, Japan). The ova, cysts and oocysts of various parasite species present were identified (Nyarango et al., 2008). The oocysts of Cryptosporidium parvum were identified by the modified Kinyoun carbol-fuchsin staining procedure (Visvesvara et al., 1997). Eggs, cysts or oocysts of the parasite present in the sample were counted and densities of each species were expressed as eggs, cysts of oocysts per litre.

Statistical Analysis: The computer statistical software, SPSS 17.0 for Windows ${ }^{\circledR}$, was used for the statistic analysis of the data. The confidence interval in $95 \%$ was used to calculate and compare the mean of parasite eggs, cysts or oocysts concentration in the samples.

\section{RESULTS AND DISCUSSION}

Parasite eggs or (oo)cysts in the raw wastewater (Influent): A total of three hundred and twenty litres (320 L) of raw sewage was collected and analysed. In all, 1648 eggs, cysts and oocysts of parasites per litre were counted during the period of the study. Ascaris spp had the highest number of eggs per litre 307 $(18.63 \%)$, this was closely followed by Taenia spp $(\mathrm{n}=287 ; 17.42 \%)$ and Schistosoma spp $(\mathrm{n}=253$; $15.35 \%$ ) while Giardia spp had the least count per litre $(\mathrm{n}=58 ; 3.52 \%)$ (Table 1). Trichuris spp and Hymenolepis spp had equal number of eggs per litre $(n=92 ; 5.58 \%)$ with mean eggs/litre of $5.69 \pm 0.44$ and $5.75 \pm 1.09$ respectively.

In Table 3, the sewage treatment plant showed a percentage reduction of $52.61 \%$ in contrast with $97.45 \%$ reduction in total parasite eggs per litre exhibited by the biosand filter. A perusal of the percentage reduction in the individual parasite eggs showed that Hymenolepis spp was the most removed by the sewage treatment plant with percentage removal of $61.67 \%$ while Ancylostoma spp (37.78\%) was the least removed. On the other hand, the highest percentage removal of parasite eggs by the biosand filter was observed for ova of Hymenolepis spp (98.91\%) followed by Trichuris spp (98.90\%).

A comparison of the mean parasites eggs/litre obtained from the biosand filter and the effluent of the sewage treatment plant using Wilcoxon's Signed Ranks Test at significant level of 0.05 revealed that there was significant difference $(p<0.05)$ between the means concentration of the parasite eggs, cysts or oocysts/litre obtained from effluent of biosand filter. A graphical comparison of the mean parasite eggs, cysts and oocysts is presented in Figure 1.

The Total number of eggs or (oo)cysts/litre of wastewater (influent) was higher than that of the effluent from the sewage treatment plant. This may be due to the adherence of the eggs/cysts of helminthes and protozoa to the suspended particles and settle out in the sedimentation tank.

However, eight (8) helminths among which are Ascaris lumbricoides, Taenia spp, Ancylostoma spp, Hymenolepis spp and Enterobius vermicularis. The WHO limit for helminth ova in wastewater for use in crop irrigation is less than one $(\leq 1)$ Helminth Ova (HO) per Litre (WHO, 2010). Mean egg counts of helminthes such as Ascaris lumbricoides, Trichuris spp, Ancylostoma spp and Toxocara spp in the untreated wastewater (influent) were higher than the effluent from the sewage treatment plant. There is a great public health risk of re-use of these waters for crop irrigation without prior treatment. However, the effluent from the biosand filter contained less than one mean egg per litre. Earlier studies by Feachem et al. (1983) and Shanthala et al. (2007) have shown that helminth ova can live in water, soil, and crops for several months or years.

In Nigeria, eggs of Ascaris lumbricoides and cysts of Protozoa particularly Entamoeba histolytica remain viable in stabilization pond effluents used to irrigate vegetables that were eaten raw (Shanthala et al., 2007). 
Table 1: Occurrence and mean of ova or (oo)cysts/litre of raw sewage (influent)

\begin{tabular}{ll|l}
\hline & $\begin{array}{l}\text { Total number } \\
\text { of eggs or } \\
\text { (oo)cysts/litre } \\
\text { of Influent }\end{array}$ & \\
Parasites & 130 & Percentage \\
\hline Cryptosporidium parvum & 253 & 7.89 \\
Schistosoma spp & 287 & 15.35 \\
Taenia spp & 135 & 17.42 \\
Ancylostoma spp & 307 & 8.19 \\
Ascaris lumbricoides & 176 & 18.63 \\
Toxocara spp & 92 & 10.68 \\
Trichuris spp & 92 & 5.58 \\
Hymenolepis spp & 118 & 5.58 \\
Enterobius spp & 58 & 7.16 \\
Giardia lamblia & $\mathbf{1 6 4 8}$ & 3.52 \\
Total & & $\mathbf{1 0 0 . 0 0}$ \\
\hline
\end{tabular}

Table 2: Occurrence and mean of ova or (oo)cysts/litre of raw sewage (influent) and effluents

\begin{tabular}{lc|lll} 
& \multirow{3}{*}{$\begin{array}{c}\text { Total number } \\
\text { of eggs or } \\
\text { Parasites }\end{array}$} & \multicolumn{3}{c}{ Mean \pm SEM } \\
\cline { 3 - 5 } of cysts/litre & $\begin{array}{l}\text { Raw Sewage } \\
\text { of Influent }\end{array}$ & (Influent) & STP Effluent & Biosand Filter Effluent \\
\hline Schistosoma spp & 130 & $8.13 \pm 0.90$ & $4.19 \pm 0.34$ & $0.13 \pm 0.09$ \\
Taenia spp & 253 & $15.81 \pm 1.33$ & $6.31 \pm 0.98$ & $0.50 \pm 0.22$ \\
Ancylostoma spp & 287 & $17.75 \pm 1.38$ & $9.56 \pm 0.98$ & $0.38 \pm 0.15$ \\
Ascaris lumbricoides & 135 & $8.56 \pm 0.89$ & $5.25 \pm 0.69$ & $0.19 \pm 0.10$ \\
Toxocara spp & 307 & $19.25 \pm 0.95$ & $7.81 \pm 0.73$ & $0.63 \pm 0.18$ \\
Trichuris spp & 176 & $10.94 \pm 1.08$ & $6.00 \pm 0.53$ & $0.50 \pm 0.16$ \\
Hymenolepis spp & 92 & $5.69 \pm 0.44$ & $3.44 \pm 0.42$ & $0.06 \pm 0.06$ \\
Enterobius spp & 92 & $5.75 \pm 1.09$ & $2.38 \pm 0.50$ & $0.06 \pm 0.06$ \\
Giardia lamblia & 118 & $7.38 \pm 0.36$ & $3.13 \pm 0.45$ & $0.13 \pm 0.09$ \\
Total & 58 & $3.75 \pm 0.48$ & $1.44 \pm 0.29$ & $0.06 \pm 0.06$ \\
\hline
\end{tabular}

$\mathrm{SEM}=$ Standard error of mean; STP $=$ Sewage treatment plant

Table 3: Average percentage reduction of eggs or (oo)cysts/litre of influent and effluents.

\begin{tabular}{|c|c|c|c|c|c|}
\hline \multirow[b]{2}{*}{ Parasites } & \multirow{2}{*}{$\begin{array}{c}\text { Average } \\
\text { Number of } \\
\text { eggs or } \\
\text { (oo)cysts/litre } \\
\text { of raw } \\
\text { sewage } \\
\text { (Influent) }\end{array}$} & \multicolumn{2}{|c|}{ STP Effluent } & \multicolumn{2}{|c|}{ Biosand Filter Effluent } \\
\hline & & $\begin{array}{c}\text { Number of } \\
\text { eggs or } \\
\text { (oo)cysts/litre }\end{array}$ & $\begin{array}{c}\text { Percentage } \\
\text { reduction } \\
(\%)\end{array}$ & $\begin{array}{c}\text { Number of } \\
\text { eggs or } \\
\text { (oo)cysts/litre }\end{array}$ & $\begin{array}{l}\text { Percentage } \\
\text { reduction (\%) }\end{array}$ \\
\hline C. parvum & 130 & 67 & 48.46 & 2 & 98.46 \\
\hline Schistosoma spp & 253 & 101 & 60.08 & 8 & 96.84 \\
\hline Taenia spp & 284 & 143 & 49.65 & 6 & 97.89 \\
\hline Ancylostoma spp & 135 & 84 & 37.78 & 3 & 97.78 \\
\hline Ascaris lumbricoides & 308 & 125 & 59.42 & 10 & 96.75 \\
\hline Toxocara spp & 175 & 96 & 45.14 & 8 & 95.43 \\
\hline Trichuris spp & 91 & 55 & 39.56 & 1 & 98.90 \\
\hline Hymenolepis spp & 92 & 37 & 61.67 & 1 & 98.91 \\
\hline Enterobius spp & 118 & 50 & 51.63 & 2 & 98.31 \\
\hline Giardia lamblia & 60 & 23 & 60.34 & 1 & 98.33 \\
\hline Total & 1648 & 781 & 52.61 & 42 & 97.45 \\
\hline
\end{tabular}

STP $=$ Sewage treatment plant 
Table 4: Wilcoxon's Signed Ranks Test of mean differences between effluents of biosand filter and sewage treatment plants.

\begin{tabular}{|c|c|c|c|c|}
\hline & & $z$ & $p$ & Decision \\
\hline \multicolumn{2}{|c|}{ Cryptosporidium spp BSF - Cryptosporidium spp STP } & -3.434 & 0.001 & BSF $<$ STP \\
\hline Schistosoma spp BSF & - Schistosoma spp STP & -3.533 & 0.000 & $\mathrm{BSF}<\mathrm{STP}$ \\
\hline Taenia spp BSF & - Taenia spp STP & -3.524 & 0.000 & $\mathrm{BSF}<\mathrm{STP}$ \\
\hline Ancylostoma spp BSF & - Ancylostoma spp STP & -3.304 & 0.001 & $\mathrm{BSF}<\mathrm{STP}$ \\
\hline Ascaris spp BSF & - Ascaris spp STP & -3.531 & 0.000 & $\mathrm{BSF}<\mathrm{STP}$ \\
\hline Toxocara spp BSF & - Toxocara spp STP & -3.523 & 0.000 & $\mathrm{BSF}<\mathrm{STP}$ \\
\hline Trichuris spp BSF & - Trichuris spp STP & -3.534 & 0.000 & $\mathrm{BSF}<\mathrm{STP}$ \\
\hline Hymenolepis spp BSF & - Hymenolepis spp STP & -3.081 & 0.002 & $\mathrm{BSF}<\mathrm{STP}$ \\
\hline Enterobius spp BSF & - Enterobius spp STP & -3.534 & 0.000 & $\mathrm{BSF}<\mathrm{STP}$ \\
\hline Giardia spp BSF & - Giardia spp STP & -2.952 & 0.003 & $\mathrm{BSF}<\mathrm{STP}$ \\
\hline
\end{tabular}

$\mathrm{BSF}=$ Biosand filter; $\mathrm{STP}=$ sewage treatment plant

$\mathrm{BSF}<\mathrm{STP}=$ the number of eggs or (oo)cysts in effluent of BSF is less than that in STP i.e. BSF is more efficient than STP at $p<0.05$.

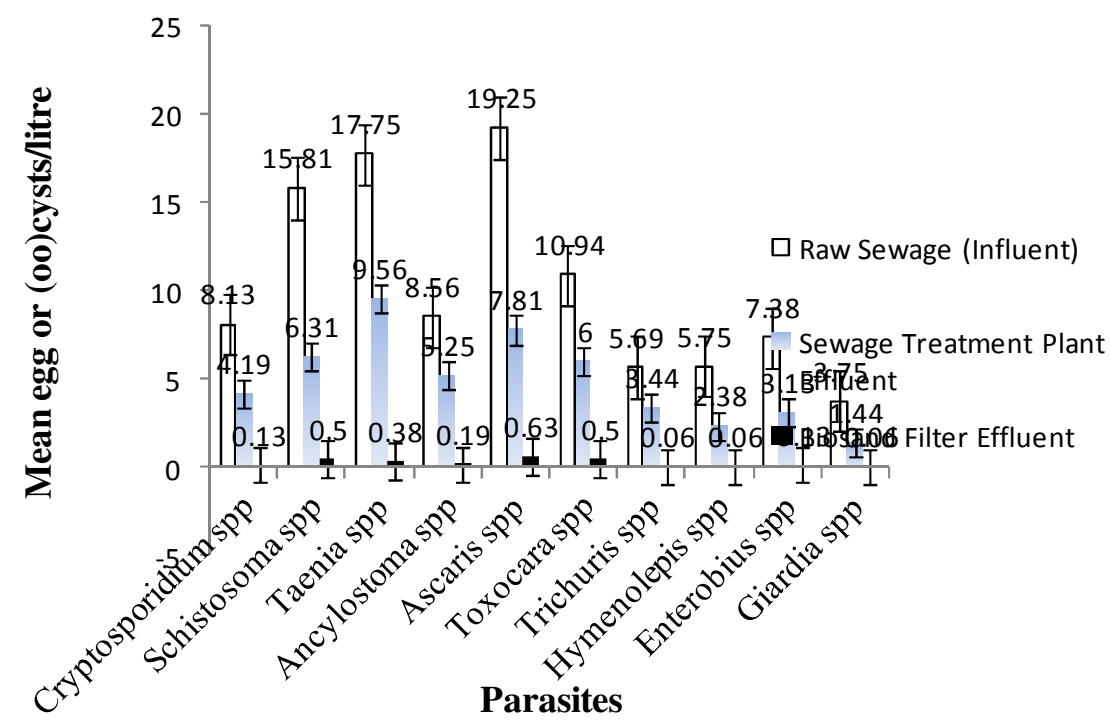

Fig: 1: Mean eggs or (oo)cysts/litre of parasites in raw sewage (influent) and effluents of Sewage Treatment Plant and Biosand Filter over the study period

Such inadequately treated sewage used for irrigation has been identified as increasing the risk towards the incidence of helminthic infections in both the farmers and consumers (Damen et al., 2007; Uneke, 2007). We also observed that farmers were using the discharged wastewater to irrigate their vegetable gardens downstream.

The presence of these ova of Taenia in the wastewater indicates the risk of human cysticercosis in members of the community eating unwashed, raw vegetables irrigated with untreated wastewater. There is also risk of bovine cystercicosis if reared cattle drink from any body of water contaminated with wastewater.
Cryptosporidiasis caused by Cryptosporidium parvum and Giardiasis cause chronic diarrhoea especially in the immunocompromised subjects can be life threatening. The (oo)cysts of both protozoan parasites were efficiently removed by the biosand filter. It is of utmost importance that pollution of water and vegetables is prevented by substituting the rapid sand filter used in the sewage plant with the biosand filter.

The rate of ova removal in biosand filter was $96.75 \%$, $97.89 \%, 97.78 .9 \%$ and $98.91 \%$ for the respective species as compared to the lower rates of ova removal by the sewage treatment plant (STP). This shows that the biosand filter is more efficient in removal of helminth ova and oocysts of Cryptosporidium spp and Giardia lamblia as indicated by the statistically significant difference when compared with the Sewage Treatment Plant. The analysis revealed that 
$52.61 \%$ of the parasite eggs, cysts and oocysts were removed by the sewage treatment plant while egg removal efficiency of the biosand filter was $97.45 \%$

We conclude that biosand filtration of wastewater (slow sand filtration) is a better alternative to rapid sand filter which is used in the conventional sewage treatment plant as it ensures removal or reduction of helminth ova and protozoan (oo)cysts.

The use of biosand filter effluent for irrigation farming in Zaria, Nigeria metropolis will prevent the parasitological pollution of vegetables.

\section{REFERENCES}

Ali, S.A. and Hill, D.R. (2003). Giardia intestinalis. Current Opinion on Infectious Diseases, 16:453 - 460.

Damen, J. G., Banwat, E.B., Egah, D. Z., and Allanana, J.A. (2007). Parasitic Contamination of Vegetables in Jos, Nigeria. Annals of African Medicine. 6(3), pp.115118.

deSilva, N.R., Brooker, S., Hotez, P.J., Montresor, A., Engels, D. and Savioli, L. (2003). Soil transmitted helminth infections: updating the global picture. Trends in Parasitology, 19, pp547 - 551.

Feachem, R., Bradley, D., Garelick, H. and Mara, D. (1983): Sanitation and disease: Health aspects of excreta and wastewater management, John Wiley and Sons, New York, NY.

Hamdani, A. and Assobhei, O. (2001). Characterisation et essays de dénitrifiction biologique d'un effluent de laiterue située dans la ville d'El Jadida (Maroc), L'eau, Ind. Nuis., 200:24 - 28.

Leclerc, H., Schwartzbrod, L. and Dei-Cas, E. (2002). Microbial agents associated with waterborne diseases. Crit. Rev. Microbiol., 28:371 - 409

Lim, Y.A.L., Wan Hafiz, W.I. and Nissapatorn, V. (2007). Reduction of Cryptosporidium and Giardia by sewage treatment processes. Tropical Biomedicine, 24(1), pp.95-104

Mustafa, U., Adnan, S., Gonul, A., Hatice, O. And Suleyman, A. (2001). Environmental pollution with soil-transmitted Helminths in Sanliurfa, Turkey. Mem Inst Oswaldo Cruz, Rio de Janeiro, 96(7):903 - 909.

Muttalib, M.A., Huq, M., Huq, J.A. and Suzuki, N. (1983). Soil pollution with Ascaris ova in three villages of Bangladesh. Yokogawa, collected paper on the control of soil transmitted helminthiasis, APCO, Tokyo, 11:66 -71 .

Nyarango, R.M., Aloo, P.A., Kabiru, E.W. and Nyanchongi, B.O. (2008). The risck of pathogenic intestinal parasite infections in Kisii Municipality, Kenya. BMC Public Health, 8, pp.237. http://www.biomedcentral.com/1471-2458/8/237 [Accessed: 20th January, 2011].
Okyay, P., Ertug, S., Gultekin, B., Onen, O. and Beser, E. (2004). Intestinal parasites prevalence and related factors in school children, a western city sampleTurkey. BMC Public Helath, 4, pp. 64. Doi: 10.1186/1471-2458-4-64

Paraskevas, P.A., Glokas, D.L. and Lekkas, T.D. (2002). Wastewater management in coastal urban areas: the case of Greece. Water Sci. Tech., 28:371 - 409.

Rodriguez-Garcia, A.J. Belmares-Taboada, J. and Hermandez-Sierra, J.F. (2004). Ascaris lumbricoidescaused risk factors for intestinal occlusion and subocclusion. Cirugia y Cirujanos, 72(1):37 - 40.

Samuel, L., Stanley, Jr. and Sharon, L. (2001). Reed: Microbes and microbial toxins: Paradigms for microbial-mucosal interactions. VI Entamoeba histolytca: Parasite-host interactions. Am. J. Physiol. Gastrointest. Liver Physiol., 280:1049 - 1054.

Shanthala, M., Hosetti, B.B. AND Stott, R.(2007). Removal of helminth parasitic eggs from waste stabilization ponds at Shimoga. The BioScan. 2(1): 914

Srikanth, R. and Naik, D. (2004). Prevalence of Giardiasis due to wastewater reuse for agriculture in the suburbs of Asmara City, Eritrea. Intern. J. of Environ. Health Res., 14(1):43- 52.

Uneke, C.J. (2007). Potential for geohelminth parasite transmission by fruits and vegetables in Nigeria: Implication for a risk profile. J. Nutri. and Environ. Med. 16(1):59-68.

United States Environmental Protection Agency - USEPA (2005). Method 1622: Cryptosporidium and Giardia in Water by Filtration/IMS/FA. Washington, U.S. Environmental Protection Agency, [Office of Water (4607), EPA 815 - R - 05 - 001 - December]. http://www.epa.gov/microbes/ [Accessed: 20th January, 2011].

Utzinger, J., N'Goran, E.K., Marti, H.P., Tanner, M. and Lengeler, C. (1999). Intestinal amoebiasis, giardiasis and geohelminthiases: their association with other intestinal parasites and reports intestinal symptoms. Trans R. Soc. Trop. Med. Hyg., 93:137 - 141

.Visvesvara G.S., Moura H., Kovacs E.N. and Wallace S. (1997). Staining and identification of coccidian parasites in persons with HIV infection. Am. J. Trop. Med. Hyg. 63, 231-235.

WHO (2010). The concept of exposure reduction in the use of excreta and greywater in agriculture. WHO Guidelines for the safe use of wastewater, excreta and greywater in agriculture and aquaculture ( $3{ }^{\mathrm{rd}} \mathrm{ed}$.). 